OPEN ACCESS

Vol. 5 No. 1, April 2017

Hal. 17 - 24
JAFFA

Journal of Auditing, Finance, and Forensic Accounting

E-ISSN: 2461-0607 ISSN: 2339-2886

http://jaffa.trunojoyo.ac.id/jaffa

\title{
DARK SIDE OF ACCOUNTABILITY OF OPERATIONAL VEHICLE MAINTENANCE EXPENSES: FRAUD IN LOCAL GOVERNMENT AGENCIES
}

Jauhari, Bambang Haryadi, Tarjo

Accounting Department, Faculty of Economics and Business, University of Trunojoyo Madura

\section{Article Info:}

Received: 9 January 2017

in revised form: 10 February 2017

Accepted: 5 April 2017

Available Online: 12 November 2017

\section{Keywords:}

Irregularities, Responsibility, Maintenance spending, Operational vehicles

\section{Corresponding Author:}

Email: m4557oe@gmail.com; haryadilee@yahoo.com; tarjo@trunojoyo.ac.id/ tarjo2005@yahoo.co

\begin{abstract}
This study aims to explore the practice of the operational vehicle maintenance expenses accountability report in local government agencies. This research is a qualitative research by using case-study method approach. The research data was collected through interview, observation, and documentation. The collected data was selected, presented, and concluded. Before being analyzed, the data was validated by using the triangulation method. The results showed the existence of irregularities in the operational vehicle maintenance expenses accountability report in local government agencies
\end{abstract}

\begin{abstract}
Abstrak; Penelitian ini bertujuan mengeksplorasi praktik laporan pertanggungjawaban pengeluaran pemeliharaan kendaraan operasional di instansi pemerintah daerah. Penelitian ini merupakan penelitian kualitatif dengan pendekatan metode studi kasus. Data penelitian dikumpulkan melalui wawancara, observasi, dan dokumentasi. Data yang telah dikumpulkan, kemudian dipilih, dipresentasikan, dan disimpulkan. Sebelum analisis, dilakukan validitas data dengan metode triangulasi. Hasil penelitian menunjukkan adanya ketidakberesan dalam laporan pertanggungjawaban pengeluaran pemeliharaan kendaraan operasional di instansi pemerintah daerah.
\end{abstract}

\section{INTRODUCTION}

The management of assets owned by local government related to security and maintenance is an important element in implementing governance and services to the public. The activities of maintaining goods owned by local government (assets) will always be associated with the budget of maintenance activities expenses that are charged to the local budget. Maintenance expenses are the costs to keep an asset in a good condition so that it is ready to use in accordance with the economic life estimation (Abdullah and Halim, 2006). Local maintenance activities expenses are one of the expenditure objects that often have a fraudulent and/or fictitious accountability report. The research conducted by Sinaga and Sidabutar (2012) provides an example of fraudulent cases in operational vehicle maintenance activities expenses that use $99.90 \%$ of the budget but there are goods owned by the local government not maintained well or even not working and missing (Abdullah, 2009).

A variety of interesting phenomena that needs to be observed regarding the realization of operational vehicle maintenance expenses activities are close to $100 \%$ in each Local Government Work Unit. These phenomena indicate that there are practices 
of fraud or unethical behavior that are not in accordance with laws by the relevant parties in the reality of operational vehicle maintenance expenses accountability. In most cases, fraud occurs because of pressure to commit fraud or encouragement to take advantage of opportunities and justification (rationalization) of those actions (Tuanakota, 2010). Fraud or unethical behavior that happens in Indonesia is known as corruption. Corruption is a major problem in the environment of local government (Barron and Clark 2006), which resulted in the delay of economic development (Ola et al., 2014).

The practice of fraud that occurs in accountability has been a concern and a rampant issue in the government all over the world including Indonesia. The form of accountability fraud in the local government is committed by the local government officials by manipulating the Accountability Letter or supporting documents that become the source of data presentation of financial statements (Sholihah and Prasetyono, 2016). Saleh and Nabila (2011) stated that many governments in the world pay serious attention to accountability and transparency issues in response to pressure from the citizens. The consequences of these corrupt practices can wipe out public trust related to the credibility of the organization and eventually affect the long-term viability of the organization (Arshad et al., 2015).

Accountability in public sector is not an easy task, it is difficult and complex and also influenced by issues such as professional and moral standards, values and attitudes of government officials who are responsible for budget management (public funds). Basri and Nabiha (2016) stated that accountability in public sector is not easy, it is difficult and dependent on issues such as professional and moral standards, values and attitudes of government officials who are responsible for public funds management. The deviation in manager's behavior is influenced by behavioral aspect in line with Fraud Triangle developed by Cressey (1953) in Tuanakota (2010) such as pressure, opportunity, and rationalization.

The study by Alhas and Abdullah (2013) suggests that criminal and unethical behavior were one of the most difficult issues to deal with within the organization and they covered all levels and activities within the organization. Sinaga and Sidabutar (2012) proved that capital expenditure has a positive and significant direct effect on fixed asset values but has a direct negative yet insignificant effect on maintenance expenses, the value of fixed assets has a positive and significant direct effect on maintenance expenses, and the relationship between capital expenditure and maintenance expenses is an indirect relation through fixed asset value. Another study by Haron et al. (2015) showed that civil servant's mentality is identified as a key barrier towards the awareness of fraud prevention. Training, law enforcement, and supervision need to be done simultaneously in order to be a solid foundation for preventing fraud successfully. It is expected that the best results can be determined on knowledge to strengthen the institutionalization of government policies to address fraud in public sector and instill the awareness that the protection of public sector revenue and assets is a thorough job for every government employee. This research examines a variety of fraud or unethical behavior in the accountability of operational vehicle maintenance expenses of Local Government Work Unit.

\section{RESEARCH METHODS}

This study uses a qualitative research approach. According to Sugiyono (2014: 347), qualitative research can be interpreted as a research method based on postpositivism/interpretive philosophy, it is used to examine the condition of natural objects, (as opposed to experiments) the data is processed in triangulation, the data analysis is inductive/qualitative, and the results of qualitative research emphasize meaning instead of generalization. The method used in this study is a case study. According to Yin (2014: 18) case study is an empirical inquiry that investigates phenomena in a real-life context, when the boundary between phenomena and context does not appear firmly and where multiple sources of evidence are used. The case study focused on a particular object which was selected for a case. This case was studied in depth so that the researcher was able to have a better understanding of the reality 
behind a visible phenomenon of operational vehicle maintenance activities expenses accountability stage. The research was conducted on XX Local Government Work Unit.

Data sources in this study were the primary and secondary data. Primary data came from informants who were directly involved in the operational vehicle maintenance activities expenses accountability stage in Local Government Institutions. Secondary data were rules, government regulations, and documents relating to the activities accountability stage. Data collection techniques included interviews, observation, and documentation. The data was analyzed by an interactive model of analysis from Miles and Huberman. According to Miles and Huberman cited by (Sugiyono, 2005: 91), the activity of qualitative data analysis was performed interactively and continuously until the data reaching a point of saturation. Data analysis activities were data reduction, data display, and conclusion drawing/verification. Data triangulation method in this study was an attempt to find the validity of data. Triangulation method used by researchers was the triangulation of sources that compared and checked back the credence of information obtained through different time and tools in qualitative research (Patton, 1987) in (Moleong, 2014: 330).

\section{RESULTS AND DISCUSSION}

\section{Accountability Procedures}

The stage of accountability for operational vehicle maintenance in XX Local Government Work Unit is conducted at the beginning of each month after all activities related to the execution of operational vehicle maintenance activities by the users in the previous month completed. The activities of operational vehicle maintenance execution include fuel/gas and lubricant activities, services, spare parts and vehicle registration activities. All administrative accountability such as receipts/invoices of operational vehicle maintenance service and fuel receipts that must be identified after being submitted by parties related to the maintenance of operational vehicles as well as fuel receipts from vehicle users and receipts/invoices of referral workshops or non-referral workshops of XX Local Government Work Unit.

The next process for the stage of accountability or the stage of accountability preparation for operational vehicle maintenance activities in XX Local Government Work Unit procedurally/routine, according to the manager who handles operational vehicle maintenance is;

"In our office, there is a manager for each operational vehicle who takes care of Accountability Letter arrangement procedure of operational vehicle maintenance activities. First, the person in charge asks the driver to submit fuel receipts by the beginning of each month. Second, the person in charge contacts the second party if there is damage on each car. We check it through maintenance service that has been determined by Local Government Work Unit. It means that there is cooperation with the Local Government Work Unit. Furthermore, if the drivers of the operational vehicles have their vehicles maintained outside the workshop that has been appointed by the office, then the driver of the vehicle needs to ask for a referral and pay in advance if the maintenance service is beyond our provisions. The maintenance service fee will be reimbursed if the person gives me a receipt as a budget user."

Based on the explanation submitted by the operational vehicle maintenance manager of XX Local Government Work Unit, the person in charge of the operational vehicle asks the driver to submit fuel receipts to the manager by the beginning of each month. The fuel receipts received by the managers should be attached to a piece of folio paper with the amount of value based on the number of liters instead of the amount of rupiah in accordance with the provisions of the local regulation. The second completeness is receipts/invoices of operational vehicle maintenance service from the workshop. Receipts/invoices from the workshop are divided into two, the first is receipts/invoices from referral workshop of XX Local Government Work Unit office and 
the second is receipts/invoices from the non-referral workshop. The payment of receipts from XX Local Government Work Unit's referral workshops is done by the beginning of each month or after disbursement from the financial department/treasurer of XX Local Government Work Unit to the Technical Activities Executive Officer of the operational vehicle. While the payment of receipts from non-referral workshops should be borne by the operational vehicle users first, after the maintenance service of operational vehicles. The maintenance service fee will be reimbursed if the person has given the receipts/invoices to the XX Local Government Work Unit's operational vehicle managers. After all completeness of accountability has reached the minimum requirement of $90 \%$ of the monthly target, the accountability can be submitted to the finance department of Local Government. The XX Local Government Work Unit's treasurer verifies/checks all completeness of operational vehicle accountability before submitting it to the Local General Treasurer. Completeness of operational vehicle maintenance activities expenses accountability arrangement in XX Local Government Work Unit is not only fuel receipts and workshop invoices, but there are other types of equipment such as Recapitulation, Maintenance Recommendation, Maintenance Activity Details, Receipt of Fuel and Service, Total Receipt, Tax Invoice (VAT, PPh22, $\mathrm{PPh} 23$ ) and SP2D of the previous month. The basis of the implementation or provisions governing the operational vehicle maintenance activities in XX Local Government Work Unit for each activity such as Fuel/Gas and Lubricants, Service and Spare Parts are regulated in Local Regulation No. yy Year 2015 on Financial Administration Guidelines for Local Government Devices Regency of Mahkota Budget Year of 2016.

\section{The Reality of Accountability}

The data completeness of operational vehicle management activities expenditure accountability documentation shall be inputted prior to the submission to the finance of XX Local Government Work Unit in accordance with activity category, namely Fuel and Lubricant receipts, maintenance service receipts/invoices, spare parts and vehicle registration. The data or document inputted in Technical Activities Executive Officer down payment control book in accordance with the license plate of each operational vehicle. In Technical Activities Executive Officer down payment control book, each activity such as maintenance service, spare parts replacement, fuel/lubricant and vehicle registration has been sorted so that the maintenance cost of each operational vehicle can be known. The Technical Activities Executive Officer down payment control book facilitates the completion of other accountability documents such as the total number of receipts for each operational vehicle, maintenance recommendations, vehicle maintenance details, maintenance recapitulation activities as well as operational vehicle maintenance tax calculations. There are three types of taxes in operational vehicle maintenance. The first is PPn, for maintenance service, spare parts, and lubricants activities. The second is $\mathrm{PPh} 22$, for spare parts and lubricants activities. And the third is $\mathrm{PPh} 23$, for maintenance service activities only.

Receipts/invoices to be accounted for either fuel receipts or workshop receipts/invoices should be attached to a piece of folio paper in accordance with the license plate of each operational vehicle. There are two kinds of receipts/invoices for operational vehicle activities accountability, namely handwritten and computer print-out receipts/invoices. The costs listed on the computer print-out receipts/invoices are most likely guaranteed, but the amount of the cost on the handwritten one is doubtful as it is most likely that the handwritten receipts/invoices become the object of fraud/corruption by interested parties. In order to convince the researcher about the validity of the receipts/invoices, especially the handwritten ones, which is used as a document of completeness of the operational vehicle expenditure activities accountability in XX Local Government Work Unit. The researcher investigates one of the referral workshops of XX Local Government Work Unit in the maintenance of operational vehicles. The researcher met one of the workshop's worker (X Workshop) who used to write the maintenance receipts/invoices of XX Local Government Work Unit's operational vehicle. The researcher explained that he wanted to interview him, but he refused it because the workshop was too crowded and busy, he was afraid that the interview would interfere his work. Finally, he agreed to be interviewed at his home 
after work. According to the workshop's officer, the Local Government Work Unit's operational vehicle manager asked for a handwritten receipt/invoice because the tax has not been listed on the original computer print-out receipts/invoices. He said that;

"The receipt is usually the original print-out... However, because there is no tax in it, they ask for a handwritten one, approximately 20 percent of the original value."

From the workshop's worker, it can be seen that the amount of tax has not been listed in the computer print-out receipts/invoices received by XX Local Government Work Unit's manager, so the manager asked the $\mathrm{X}$ workshop's worker to add the tax on the workshop receipts/invoices 20 percent of the original memo. To prove the statement of X workshop's worker, the researcher cross-checked the original computer print-out receipts/invoices with the handwritten version from the workshop's officer of one of the operational vehicles in the accountability document. There was $20 \%$ addition to the original computer print-out receipts in the obtained results. The researcher came to another workshop that also became a client/referral for XX Local Government Work Unit's operational vehicle maintenance, Y Workshop, for a further and more convincing investigation. Here is the statement of the Y Workshop's owner;

"Yes....(while smiling, reluctantly answering the question), the total value will be added by 20 percent...he said it's for tax expenses...Actually, there is no tax, but 20 percent is added for tax.. that's it, Sir".

Based on the explanation from both workshops, the handwritten receipt/invoice is at the request of $\mathrm{XX}$ Local Government Work Unit's manager with an additional nominal of 20 percent from the actual price/total value for taxes. Given this incident, it did not rule out the existence of things that lead to fraud/corruption through handwritten receipts/invoices. Then, the researcher went on to question the possibility of another request from XX Local Government Work Unit's manager related to the receipts/invoices to both workshops. Here is a statement from X Workshop's officer on the question of whether the XX Local Government Work Unit's manager ever asked for a blank receipt/invoice from the workshop;

"Yes...I'm not sure, maybe they're afraid of mistakes or what, usually we correct each other, sometimes we are wrong so it's usually being rewritten."

From the statement, it can be explained that the XX Local Government Work Unit's manager is asking for a blank receipt/invoice to the workshop's worker for no apparent reason. The statement from the workshop's worker explained that he was unaware and was probably afraid because sometimes the workshop made a mistake in writing the receipts/invoices. Supposedly, if there was a mistake in writing a receipt/invoice from the workshop then the workshop must correct it, instead of asking for a blank receipt/invoice from the workshop, because it could be misused and leads to fraud/corruption. It is in line with the statement of the Y Workshop's owner who also said the same thing, here is his statement;

"Yes......some people ever asked for a blank receipt ... (sighing with a smile) he said it would be included in the Accountability Letter or afraid that there's a mistake in the writing or a wrong date, it's usually like that, Sir".

The statement of $\mathrm{Y}$ Workshop's owner also strengthens the indication of unjustifiable action or unethical behavior by XX Local Government Work Unit's managers in the completeness of operational vehicle maintenance activities expenditure accountability documents. The information from both workshops is also strengthened by the manager himself who said that there is a request for blank receipts and other additional receipts for certain interests, such as the following statement of XX Local Government Work Unit's manager;

"Yes, if it is needed, Sir... The receipts are sometimes not clear, so we need a correction. Sometimes, there is a mistake in the writing of the receipt or some crossed out words, so the receipt becomes doubtful and a correction is needed. However, the correction must be made in front... we correct it in place, Sir..." 
Based on the statement of XX Local Government Work Unit's manager, blank receipt/invoice is requested to the workshop if it is really needed for correcting workshop's receipt/invoice if there is any ambiguity or mistake in the writing. From the description of both referral workshops of XX Local Government Work Unit and strengthened by the statement of XX Local Government Work Unit's manager indicates the existence of potential fraud/corruption on the writing of workshop's memo/receipt is done by the XX Local Government Work Unit's manager in cooperation with a third party. Potential fraud/corruption in operational vehicle maintenance activities is an opportunity that can be done at any time by the manager with the third party. It may happen because of a weak supervisory system so that employees/perpetrators feel they have the power or ability to exploit the situation and may cheat. Usually employees or perpetrators of fraud are well aware of the weaknesses in the organization's internal control so that it is easy to know the available opportunities to commit fraud/corruption related to their work, as stated by Ewa and Udoayang (2012) quoted by Mansor (2015), who conclude that employees and leaders who have been around for years know quite well the weaknesses in internal control and have gained enough knowledge to commit a crime successfully with no fear and stress.

Another reality that exists in the operational vehicle management activities expenditure accountability stage of XX Local Government Work Unit is not only by an additional 20 percent of the workshop's receipts and the request for a blank receipt, but there is still another reality that has led to unethical practices undertaken by the XX Local Government Work Unit's manager who has rationalized his own actions for the common or organization good. The XX Local Government Work Unit's manager asked for additional receipts/invoices to the workshop as stated by the workshop's officer;

"Yes... (smiling while hesitant in answering) I think so, there is like an oil change or sometimes the oil was changed in other workshop but the manager asked for a receipt from the workshop because the office is in cooperation with the workshop."

The workshop explains that there is a request for additional receipts/invoices from XX Local Government Work Unit manager such as additional receipts/invoices of operational vehicle's oil change and also there are operational vehicles that change its oil outside the referral workshop but asking for receipts/invoices from the workshop because the office is in cooperation with the workshop. It is very unfortunate and only becomes a waste of operational vehicle maintenance expenses. Either for whom the outcome of such unethical behavior that should not have occurred. To get the answer on how the reality is, the researcher tried to get a straight answer from XX Local Government Work Unit's manager whether it is true there is a request for additional receipts/invoices from the workshop and what is the purpose. Here is the statement;

"O.... obviously, Sir..., usually for service and lubricant memos for the purpose of tactical funds for activities that are not budgeted and for the common good instead of the benefit of the individual. For example, for guests or for donations, even we need funds or fees in the process of making this Accountability Letter, Sir. Where else can we get is, Sir? Thus, we need the cooperation of the cooperated workshops. Obviously, Sir. It should be underlined that these interests are not individual interests. This is a common interest where both parties know, the maintenance service receipts from the workshop and so on. It also needs cooperation, Sir. They also know about this. We need a budget out of the routine, Sir. It concerns the operational problem of this car....., it is logical."

Based on the explanation from XX Local Government Work Unit's manager, the additional receipt/invoice from the workshop does exist, such as maintenance service receipt/invoice and replacement of lubricant/oil tap. The results of the additional receipt/invoice are used as tactical funds for activities that have no budget and for common interests, not for the benefit of the individual. Furthermore, XX Local Government Work Unit's manager explained that tactical funds are used for activities that do not have a budget. for example, if there are guests or request for donations. Even for Accountability Letter arrangement activities or the preparation of the accountability stage itself requires other costs. XX Local Government Work Unit's manager added that to get a tactical fund with no activity budget, he must work with 
the workshop to get the fund. XX Local Government Work Unit's manager confirms that everything is done for common interests, not for individual interest. Everyone already knows the purpose. Even such actions are considered logical because the tactical funds are used for budgets outside the routine of operational vehicles maintenance activities.

Any unlawful conduct or behavior carried out by various parties/individuals associated with the process of operational vehicle management activities expenditure accountability in XX Local Government Work Unit is classified as a fraud/corruption that causes the waste of local government budget. The act of fraud/corruption by XX Local Government Work Unit individuals occurs not only because of the three fundamental factors contributing to fraud based on the famous Fraud Triangle Theory by Cressey (1950) but also because they have the ability or capacity to do the fraud itself. As stated by Wolfe and Hermanson (2004) in (Mansor, 2015), that although swindlers may have pressure, the opportunity to deceive and rationalize ideology betrays trust, swindlers cannot hide it unless they have the ability to do so.

The next process if all completeness of accountability documents have been completely inputted and printed is XX Local Government Work Unit's manager asks for the signature of the related parties as well as a Recapitulation signed by the Head of the local government work unit, Maintenance Recommendation signed by four people (Assets Management, Technical Activities Executive Officer, Head of General Affair, Head of Local Government Work Unit), Details of Maintenance Activities signed by the Head of Local Government Work Unit, the total receipts signed by the Assets Management, Receipts for the cost of each operational vehicle are signed by four persons (Vehicle Users, Technical Activities Executive Officer, Proxy of Budget User and Expenditure Treasurer). After all completeness of administrative accountability documents are completed and verified by the expenditure treasurer, it will be duplicated in two copies, the original Accountability Letter would be deposited to the Local General Treasurer, the first copy as the financial archive of the Local Government Work Unit and the second copy as the archive of Technical Activities Executive Officer.

\section{SUMMARY AND ADVICE}

Prudence and thoroughness are required in the accountability stage of operational vehicle maintenance expenses. The completeness of the accountability documents to be submitted to the local treasury must be verified/checked by the treasurer of local government work unit as an internal control to minimize fraud or unethical behavior. However, fraud or unethical behavior occurs due to the weak internal control in organization/XX Local Government Work Unit. Employees/perpetrators feel that they have the power or ability to exploit the situation and are likely to commit fraud/corruption. As a result, fraud or unethical behavior occurs in operational vehicle maintenance accountability stage in various modes. There should be no fraud or unethical behavior perpetrated by the unscrupulous managers of operational vehicle maintenance in XX Local Government Work Unit although the results of such fraud are used for mutual or organizational interest.

The limitation of this research is the lack of transparency from the informants in XX Local Government Work Unit's financial department who do not want to be exposed/interviewed for information desired by the researcher. The researcher hopes that the results of this study will provide additional benefits to readers and other interested parties. The researcher also provides advice to XX Local Government Work Unit to reduce the potential for malfeasance in activities and programs. The XX Local Government Work Unit should be able to manage all activities and programs that have the potential for fraud/corruption by fixing all the problems and weaknesses. Efforts that can be followed up by XX Local Government Work Unit in fixing the problems and weaknesses that exist in operational vehicle maintenance activities accountability is to have a strong internal control that is able to reduce fraud/corruption and unethical behavior on the employees, especially in the stage of activities' and programs' accountability. 


\section{DAFTAR PUSTAKA}

Abdullah, S 2009. Optimalisasi Pengelolaan Aset Daerah.

Abdullah, S. and Halim, A. 2006. Studi atas Belanja Modal pada Anggaran Pemerintah Daerah dalam Hubungannya dengan Belanja Pemeliharaan dan Sumber Pendapatan. Jurnal Akuntansi Pemerintahan. Volume 2, Nomor 2, hal 17-32

Alhas, N. and Abdullahi, Y. S. 2013. Criminal and Unethical Behaviours in Organisations: Misuse of Assets and False or Misleading Advertising. Global Journal of Human-Social Science Research, 13.

Alison. 2006. Fraud Auditing (Bagian Pertama Dari Dua Tulisan), http://www.reindo.co.id (30/09/2016)

Arsyad, R., Asyiqi, W. A., Razali, W. M. and Bakar, N. A. 2015. Catch the "Warning Signals": The Fight against Fraud and Abuse in Non-Profit Organisations. Procedia Economics and Finance. Vol. 28, 114-120.

Ashforth, B. E. and Anand, V. 2003. The normalization of corruption in organizations. Research in Organizational Behavior, Vol. 25. Pp 1-52.

Barron, P. and Clark, S. 2006. Decentralizing inequality. Center-periphery relations, local governance, and conflict in Aceh, Conflict Prevention and Reconstruction Paper.

Basri, H. and Nabiha, A. S. 2016. Accountability of Local Government: The Case of Aceh Province, Indonesia. Asia Pacific Journal of Accounting and Finance, 3.

Garg, A. and Deshmukh, S. 2006. Maintenance management: literature review and directions. Journal of Quality in Maintenance Engineering, 12, 205-238.

Haron, R., Mohamed, N. and Paino, H. 2015. Misappropriation of assets: A deception of leakages in Malaysian public sector. Proceedings of the International Conference on Accounting Studies (ICAS) 2015 17-20 August 2015, Johor Bahru, Johor, Malaysia

Harrison, A. 2006. United Nation statistics division. Retrieved from United Nation website: https://unstats.un.org/unsd/nationalaccount /aeg/papers/ m4EconAssets.PDF

Mansor, N. 2015. Fraud Triangle Theory and Fraud Diamond Theory. Understanding the Convergent and Divergent For Future Research. International Journal of Academic Research in Accounting, Finance and Management Science, 1, 38-45.

Moleong, J. Lexy. 2014, Metodologi Penelitian Kualitatif, Bandung: PT. Remaja Rosdakarya.

Ola, A., Mohammed, A. and Audi, MS. 2014, Effects Of Corruption On Economic Development In Nigeria

Peraturan Bupati Mahkota Nomor yy Tahun 2015 Tentang Pedoman Penatausahaan Keuangan Bagi Satuan Kerja Perangkat Daerah Di Lingkungan Pemerintah Kabupaten Mahkota Tahun Anggaran 2016.

Robinson, M. Resources, citizen engagement and democratic local governance. Project Planning Workshop, 2004

Saleh, Danilah and Siti-Nabiha, AK. "Accountability Practice at Local Government of Malaysia." Proceeding $2^{\text {nd }}$ International Conference on Business and Economic Research (2nd Icber 2011).

Sholihah, Siti dan Prasetyono. 2016. Fraud Pelaporan Keuangan Sektor Publik. Journal of Auditing, Financed and Forensic Accounting. Vol. 04 No. 1. April 2016 Hal. 53 61.

Sinaga, T. and Sidabutar, R. C. 2012. Pengaruh Belanja Kendaraan Dinas dan Nilai Kendaraan Dinas Terhadap Belanja Pemeliharaan Kendaraan Dinas Pada Dinas Provinsi Jawa Barat. Jurnal Ekonomi dan Bisnis, 11-22

Sugiyono, 2014, Metode Penelitian Manajemen, Bandung: ALFABETA, CV.

Tuanakotta, Theodorus M, 2010, Akuntansi Forensik \& Audit Investigasi, Jakarta: Salemba Empat.

Yin, Robert K. 2014. Studi Kasus Desain \& Metode. Rajawali Pers. Jakarta. 